ACTA THERIOLOGICA

Vol. 29, 20: 251-258, 1984

\title{
Progesterone Concentration and their Seasonal Changes during the Estrus Cycle of Chinchilla
}

\section{Joanna GROMADZKA-OSTROWSKA \& Elżbieta SZYLARSKA-GOŹDŹ}

Gromadzka-Ostrowska J. \& Szylarska-Góźdź E., 1984: Progesterone concentration and their seasonal changes during the estrus cycle of chinchilla. Acta theriol., 29, 20: 251-258 [With 1 Table \& 2 Figs.]

According to the number of cornified cells, epithelial cells and leucocytes in vaginal smears the stages of the estrus cycle were determined. Estrus was typified by a vaginal smears which contains cornified cells and no leucocytes and is accompanied by vaginal perforation. The data were obtained during spring (May - June), summer (July - September) and autumn-winter (October - February). The progesterone concentration in plasma during different estrus cycle stages were measured by radioimmunoassay technique. During the chinchilla estrus cycle progesterone concentration varied between 0.1 to $14.0 \mathrm{ng} / \mathrm{ml}$ of plasma; at the metaestrus period is $7.21-9.74 \mathrm{ng} / \mathrm{ml}$ and at the proestrus period is $0.4-0.8 \mathrm{ng} / \mathrm{ml}$. Seasonal changes in progesterone concentrations at the same pattern during the estrus cycle were also determined. The lowest progesterone level $(4.19 \mathrm{ng} / \mathrm{ml})$ were found in the summer season, whereas a significantly higher progesterone concentrations were determined in the spring $(6.04 \mathrm{ng} / \mathrm{ml})$ and in the autumn-winter $(5.29 \mathrm{ng} / \mathrm{ml})$ seasons.

Physiological Laboratory, Warsaw Zoological Garden, Ratuszowa 1/3, 03-461 Warszawa, Poland].

\section{INTRODUCTION}

Hormone patterns during the estrus cycle and the interactions between pituitary and gonadal hormones during the estrus cycle have been studied in different myomorph rodents with short estrus cycle such as hamsters (Ridley \& Greenwald, 1975; Shaikh \& Saksena, 1972; Saidapur \& Greenwald, 1978), mice (Michael, 1976) and rats (Butcher et al., 1974; Ogle \& Kitay, 1977; Page \& Butcher, 1982). With the exception of the guinea-pigs (Challis et al., 1971; Feder et al., 1968; Heap et al., 1967; Joshi et al., 1973), little attention has been directed towards the hormonal secretion in rodents with a long estrus cycle from suborder $\mathrm{Hy}$ stricomorpha in which belong chinchillas. There is only one report on circulating levels of progesterone during the estrus cycle of chinchillas (Bookhyser \& Aulerich, 1980), seasonal fluctuations in progesterone concentrations during estrus cycle have not been reported.

In the present study we report the measure of plasma progesterone concentration in the same chinchillas in which we previously characterized vaginal smear patterns and seasonal changes in sexual cycle length (Szylarska \& Gromadzka, 1984). 


\section{MATERIALS AND METHODS}

Studies were performed on 12 chinchilla females (Chinchilla laniger Molina, 1782) 3-6 years old in good general health. All the animals were housed individually in the natural light. Cages were kept in room at temperature $4^{\circ} \mathrm{C}$ in winter and $25^{\circ} \mathrm{C}$ in summer, humidity was $90 \%$ and $65 \%$ respectively. Chinchilla males were housed in the same room.

Feeding system was equal for all animals. Diet consisted of concentrated feeding stuff according to Jarosz \& Rżewski (1969), meadow hay, fruits or green forage and water ad lib.

Evidence for the estrus cycles was based on the changes in vaginal smears which were taken daily, during the whole year, with a plastic loop and stained with $0.1 \%$ Toluidine Blue. Analysis of vaginal smears were arranged to vaginal perforation which is real indication of estrus in hystricomorph rodents (Weir, 1967).

The following criteria, similar to those employed by others (Michael, 1976; Jarosz, 1973; Dobrowolska \& Gromadzka, 1978), were used for identification of cycle stages: Estrus (E) - cornified cells dominated, metaestrus (M) a few cornified cells and nucleated cells, diestrus (D) - great number of leucocytes and mucus, proestrus (P) - large number of small nucleated cells.

Length of estrus cycle was on the average 35 days and varied during the years 22-27 days in spring, 33-36 days in summer and 70-90 days in autumnwinter (Szylarska \& Gromadzka, 1984).

blood was obtained from each animal in particular estrus cycle stages using bleeding technique with modification of Stoltz \& Bendall (1975). This technique find application when a repeated sampling are available for obtaining serial blood samples without killing the animals and it has been reported that blood obtained by this technique yields plasma factors concentration within the normal range (Marimoto et al., 1975). The tail was severed about $5 \mathrm{~mm}$ from the tip with a scalpel without anaesthesia. The first drop of blood was wipp off, the next drops were collected into a heparynized glass tubes $0.8-1.0 \mathrm{~mm}$ in diameter and $100 \mathrm{~mm}$ in length.

Plasma was removed after centrifugation and stored at $-20^{\circ} \mathrm{C}$ until assayed. Progesterone levels in plasma samples were determined by directly radioimmunoassay technique according to Stupnicki (1975). Each progesterone samples was run in duplicate. Progesterone concentrations were expressed as a nanograms per mililiter of plasma $(\mathrm{ng} / \mathrm{ml})$, the lowest detectable concentration was $0.1 \mathrm{ng} / \mathrm{ml}$, coefficients of variation within assays were $7-13 \%$, between assays were $9-15 \%$.

The significant differences between mean values for all the estrus cycle stages were calculated using the Student $t$ test.

\section{RESULTS}

Progesterone levels in chinchilla females varied between $0.3-$ $-14.0 \mathrm{ng} / \mathrm{ml}$ of plasma (Fig. 1). Mean value for whole year was $5.04 \pm 0.49 \mathrm{ng} / \mathrm{ml}$.

During the proestrus period the progesterone concentration was very low $(0.58 \pm 0.33 \mathrm{ng} / \mathrm{ml})$, it increased progressively at the estrus $(4.28 \pm 0.48 \mathrm{ng} / \mathrm{ml})$ to reach a maximum level at the metaestrus $(8.17 \pm 0.76 \mathrm{ng} / \mathrm{ml})$ after which it declined steadily at the diestrus period $(2.79 \pm 0.32 \mathrm{ng} / \mathrm{ml})$ and low values were observed at the next proestrus period. 


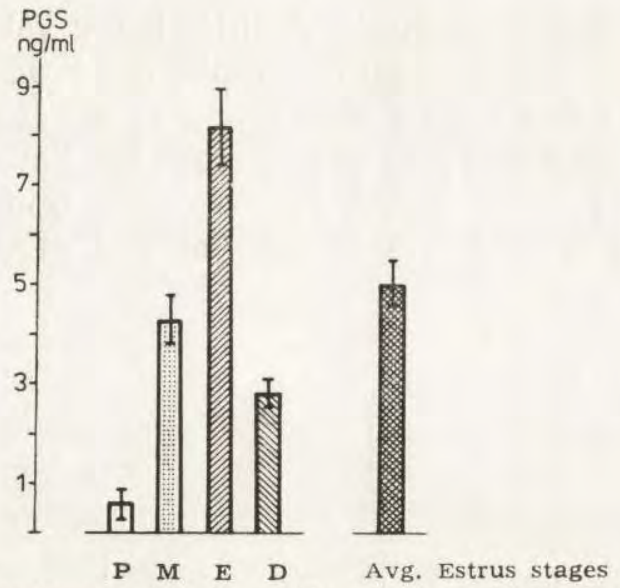

WFig. 1. Concentration of progesterone in chinchilla plasma obtained during three investigated seasons at different stages of the estrus cycle $(\bar{x} \pm \mathrm{SE})$.

Vertical bars represents the standard errors (SE).

Table 1

Progesterone concentration $(\mathrm{ng} / \mathrm{ml})$ in plasma of chinchilla females at different stages of the estrus cycle in three investigated seasons (mean values $\pm S E$ ). 1, 2, 3 Indicate the significant differences between the seasons.

\begin{tabular}{lclc}
$\begin{array}{c}\text { Season } \\
\text { (months) }\end{array}$ & $\begin{array}{c}\text { Estrus } \\
\text { cycle, stage }\end{array}$ & Mean \pm SE & $\begin{array}{c}\text { Range } \\
\text { Min. }- \text { Max. }\end{array}$ \\
\hline Season I & E & $5.45 \pm 1.29^{1}$ & $2.4-7.4$ \\
(May - June) & M & $9.74 \pm 1.88$ & $5.0-14.0$ \\
& D & $3.40 \pm 0.95$ & $1.4-3.7$ \\
& P & 0.50 & $0.1-0.7$ \\
Season II & E & $3.26 \pm 0.67^{1,2}$ & $1.7-4.3$ \\
(July - Sept.) & M & $7.21 \pm 1.62$ & $2.6-14.9$ \\
& D & $2.02 \pm 0.43^{3}$ & $1.2-3.2$ \\
& P & 0.40 & $0.1-0.8$ \\
Season III & E & $4.38 \pm 0.12^{2}$ & $4.2-4.6$ \\
(Oct. - Febr.) & M & $8.15 \pm 0.74$ & $6.4-12.5$ \\
& D & $3.23 \pm 0.29^{3}$ & $2.3-3.9$ \\
& P & 0.80 & $0.1-1.6$ \\
\hline
\end{tabular}

Basing on the whole year's observations of chinchilla's delivery (Szylarska \& Gromadzka, 1984) progesterone concentration was determined in three following seasons:

I - remained from May to June,

II - remained from July to September,

III - remained from October to February.

The same pattern of progesterone concentration consisted one major surge in metaestrus has been observed in three investigated seasons (Fig. 2). 
The highest progesterone concentrations $(6.04 \pm 1.07 \mathrm{ng} / \mathrm{ml})$ were found in season I (May to June). A little lower values we obtained in season III (Oct. to Febr.,5.29 $\pm 0.70 \mathrm{ng} / \mathrm{ml}$ ), the lowest progesterone concentrations $(4.19 \pm 0.89 \mathrm{ng} / \mathrm{ml})$ were found in the II season (July to Sept.).

During the whole year progesterone level at the proestrus period varied between 0.1 to $0.8 \mathrm{ng} / \mathrm{ml}$, at the estrus from 1.7 to $6.8 \mathrm{ng} / \mathrm{ml}$, at the metaestrus from 6.4 to $14.4 \mathrm{ng} / \mathrm{ml}$ and at the diestrus from 1.4 to $3.9 \mathrm{ng} / \mathrm{ml}$.

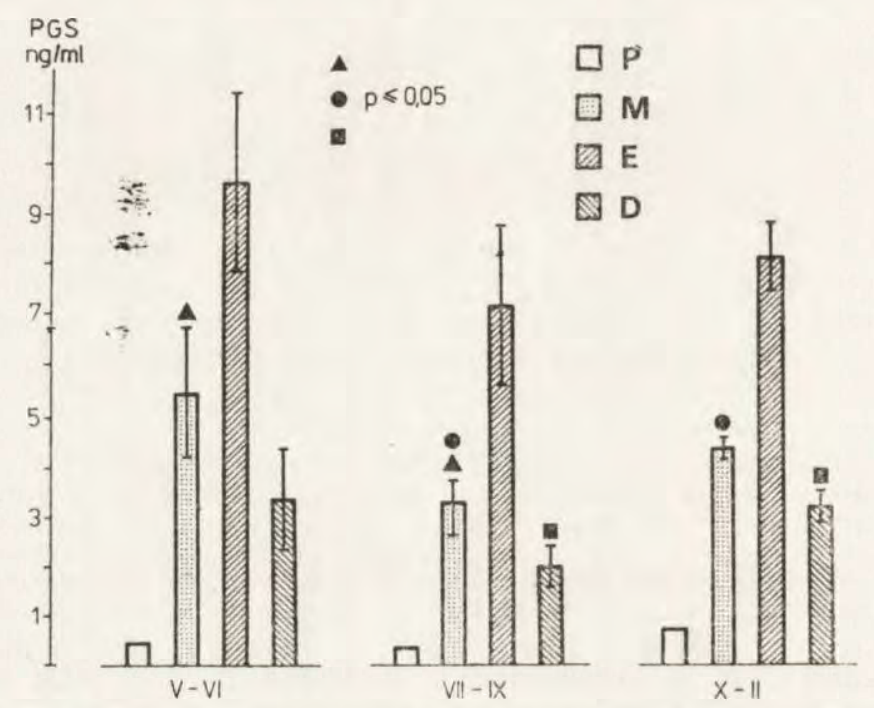

Fig. 2. Seasonal changes in progesterone concentrations at different stages of the chinchilla estrus cycle.

Mean values and standard errors are given. Symbols above columns indicate significant differences between stage of the cycle. $\mathrm{P}-$ proestrus, $\mathrm{M}-$ metaestrus, E - estrus, D - diestrus.

\section{DISCUSSION}

Presented in this paper progesterone concentration patterns during estrus cycle were rather in agreement with that described previously by Bookhyser \& Aulerich (1980). They constated that the lowest mean progesterone value was during the 6 days period included the first day of vaginal perforation; $4-8$ days latter there was a dramatic rise in plasma progesterone and the highest level of the steroid was found in the luteal phase.

The progesterone patterns found in chinchilla females during estrus cycle was similar to those found in common voles (Dobrowolska \& Gromadzka, 1978) in which progesterone determination showed a significantly higher concentration in plasma collecting during meaestrus than in all other stages.

It is difficult to make a comprehensive comparison between levels of progesterone in the cyclic chinchillas and those of others hystri- 
comorph rodents. Many previous studies used only guinea-pigs (Challis et al., 1971; Feder et al., 1968; Joshi et al., 1973; Heap et al., 1967) whereas the other species from this suborder have not been investigated yet or reported on small numbers of animals with no repeated sampling during the estrus cycle: green acouchi (Rowlands et al., 1970) and cuis. (Tam, 1973). The level of progesterone reported in this study for cyclic chinchilla females varied between 0.1 to $14.0 \mathrm{ng} / \mathrm{ml}$. This is higher than those found for guinea pigs $(0.5-2.8 \mathrm{ng} / \mathrm{ml}$; Challis et al., 1971; $0.3-3.9 \mathrm{ng} / \mathrm{ml}$; Feder et al., 1968), green acouchi $(12.6 \mathrm{ng} / \mathrm{ml}$; Rowlands: et al., 1970), voles (1.8-7.69 $\mathrm{ng} / \mathrm{ml}$; Dobrowolska \& Gromadzka, 1978) and rats $(2.0-7.0 \mathrm{ng} / \mathrm{ml}$; Butcher et al., 1974), lower than those found for cuis (18 ng/ml; Tam, 1973), Syrian hamsters $(0.8-18.2 \mathrm{ng} / \mathrm{ml}$; Saidapur \& Greenwald, 1978) and mice (5.0-64.0 ng/ml; Michael, 1976).

In the natural population the seasonal changes of environment, especially of photoperiod, affect the breeding stage (Charlton et al., 1976; Rollag \& Niswender, 1976; Ravault \& Ortavant, 1977; Dobrowolska \& Gromadzka, 1983). In the wild chinchillas have a breeding season from April to September (Pearson, 1948). In our latitude chinchillas are a polyestric animals however they have a major breeding period betwen November to May (Weir, 1967; Jarosz, 1973) or between November to April (Szylarska \& Gromadzka, 1984). In the present study we have found the lowest progesterone concentrations during the summer season and significant higher concentrations during the spring and autumnwinter seasons - both are the breeding period in the investigated chinchillas.

It seems that the sexual activity in chinchillas depends on the increasing daylight as suggested by Wessell (1963). Similar relation seems to be indicated by our study which show that the maximum intensification of chinchilla's sexual function is between December to January (main delivery peak was found in March) (Szylarska \& Gromadzka, 1984). In the summer months the reproductive function in chinchillas decreased parallel to decrease in progesterone concentration. This last occurrence may be due to a high prolactin level during long daylight period (Relkin, 1972; Bittman \& Goldman, 1979), which may caused a morphological luteolysis in chinchillas as well as in rats (Beck et al., 1977).

Acknowledgements: The authors are most grateful to Prof. R. Stupnicki from Institute of Animal Physiology and Nutrition, Polish Academy of Sciences for the progesterone antibodies and for enabling us to perform a radioimmunoassay analysis, and to Miss B. Zalewska for her valuable assistance in animal keeping and blood sampling.

\section{REFERENCES}

1. Beck W., Engelbart S., Gelato M. \& Wuttke W., 1977: Antigonadotrophic effect of prolactin in adult castrated and immature female rats. Acta endocr., 84:$62-71$. 
2. Bittman E. L. \& Goldman B. D., 1979: Serum levels of gonadotrophin in hamsters exposed to short photoperiods: effects of adrenalectomy and ovariectomy. J. Endocr., 83: 113-118.

3. Bookhyser K. M. \& Aulerich R. J., 1980: Consumption of food, body weight perineal colour and levels of progesterone in the serum of cyclic female chinchillas. J. Endocr., 87: 213-219.

4. Butcher R. L., Collins W. E. \& Fugo N. W., 1974: Plasma concentration of LH, FSH, prolactin, progesterone and estradiol $17 \beta$ throughout 4-day estrus cycle of the rat. Endocrinology, 94: 1704-1708.

5. Challis J. R. G., Heap R. B. \& Illingworth D. V., 1971: Concentrations of estrogen and progesterone in the plasma of non-pregnant and lactating guinea-pigs. J. Endocr., 51: 333-345.

6. Charlton H. M., Grocock A. C. \& Ostberg A., 1976: The effect of pinealectomy and superior cervical ganglionectomy on the testis of the vole (Microtus agrestis). J. Reprod. Fert., 48: 377-379.

7. Dobrowolska A. \& Gromadzka J., 1978: Relationship between haematological parameters and progesterone blood concentration in different stages of estrus cycle in common vole (Microtus arvalis). Comp. Bioch. Physiol., 61A: 483-485.

8. Dobrowolska A. \& Gromadzka J., 1983: Influence of photoperiod on morphological parameters, androgen concentration, haematological indices and serum protein fractions in common vole (Microtus arvalis). Comp. Bioch. Physiol., 74A: $427-433$.

9. Feder H. H., Resko J. A. \& Goy R. W., 1968: Progesterone concentrations in the artherial plasma of guinea-pigs during the estrus cycle. J. Endocr., 40: $505-513$.

10. Heap R. B., Perry J. S. \& Rowlands I. W., 1967: Corpus luteum function in the guinea-pig: arterial and luteal progesterone levels and the effects of hysterectomy and hypophysectomy. J. Reprod. Fert., 13: 537-553.

11. Jarosz S. \& Rżewski W., 1969: Chów szynszyli. Państwowe Wydawnictwo Rolnicze i Leśne: 23-59.

12. Jarosz S., 1973: The sexual cycle in chinchilla (Chinchilla laniger). Zool. pol., 23: $119-128$.

13. Joshi H. S., Watson D. .J. \& Labhsetwar A. P., 1973: Ovarian secretion of estradiol, estrone, $20 \alpha-\mathrm{OH}$-progesterone and progesterone during the estrus cycle of the guinea-pig. J. Reprod. Fert., 35: 177-181.

14. Morimotó S., Kenko H., Kenzo U. \& Takeda R., 1975: Influence of adrenal enucleation on plasma renin substrate concentration in saline loaded and unilaterally nephroadrenalectomized rats. Endocrinology, 96: 1314-1319.

15. Michael S. D., 1976: Plasma prolactin and progesterone during the estrus cycle in the mouse. Proc. Soc. Exp. Biol. Med., 153: 254-257.

16. Ogle T. F. \& Kitay J. J., 1977: Ovarian and adrenal steroids during pregnancy and the oestrus cycle in the rat. J. Endocr., 74: 89-98.

17. Page R. D. \& Butcher R. L., 1982: Follicular and plasma patterns of steroids in young and old rats during normal and prolonged estrus cycle. Biol. Reprod., 27: $383-392$.

18. Pearson O. P., 1948: Life history of mountain viscachas in Peru. J. Mammal., 29: $345-374$.

19. Revault J. P. \& Ortavant R., 1977: Light control of prolactin secretion in sheep. Evidence for photo-inducible phase during a diurnal rhythm. Ann. Biol. Anim. Bioch. Bioph., 17: 459-473.

20. Relkin R., 1972: Rat pituitary and plasma prolactin levels after pinealectomy. J. Endocr., 53: 179-180. 
21. Ridley K. \& Greenwald G. S., 1975: Progesterone levels measured every two hours in the cyclic hamster. Proc. Soc. Exp. Biol. Med., 149: 10-12.

22. Rollag M. D. \& Niswender G. D., 1976: Radioimmunoassay of serum con. centration of melatonin in sheep exposed to different lighting regimes. Endo crinology, 98: 482-497.

23. Rowlands I. W., Tam H. W. \& Kleiman D. G., 1970: Histological and biochemical studies on the ovary and of progesterone levels in the systemic blood of the green acouchi (Myoprecta pratti). J. Reprod. Fert., 22: 533-545.

24. Saidapur S. K. \& Greenwald G. S., 1978: Peripheral blood and ovarian levels of six steroids in the cyclic hamster. Biol. Reprod., 18: 401-408.

25. Shaikh A. A. \& Saksena K., 1972: Cyclic changes in uterine venous and peripheral plasma levels of $\mathrm{F}$ prostaglandins correlated with peripheral progesterone levels in the golden hamster. Adv. Biosc., 9: 635-639.

26. Stoltz D. R. \& Bendall R. D., 1975: A simple technique for repeated collection of blood samples from mice. Lab. Anim. Sci., 25: 353-354.

27. Stupnicki R., 1975: Direct radioimmunoassay of progesterone in plasma of farm animals. Endocrinologie, 66: 145-151.

26. Stoltz D. R. \& Bendall R. D., 1975: A simple technique for repeated collection seasonal fluctuations in female chinchillas (Chinchilla laniger). Zw. Lab., in press.

29. Tam W. H., 1973: Progesterone levels during the estrus cycle and pregnancy in the cuis (Galea musteloides). J. Reprod. Fert., 35: 105-114.

30. Weir B. J., 1967: Aspects of reproduction in some hystricomorph rodents. $\mathrm{Ph}$. D. thesis, University of Cambridge.

31. Wessell K., 1263: Does light affect reproduction in chinchillas too. Der Deutsche Pelztierzuchter, 37: 91-93.

Acceptei, January 15, 1984.

\section{Joanna GROMADZKA-OSTROWSKA i Elżbieta SZYLARSKA-GOŹDŹ}

\section{SEZONOWA ZMIENNOSC STEZZENIA PROGESTERONU W CYKLU ESTRALNYM U SAMIC SZYNSZYLA MAEEGO}

\section{Streszczenie}

Badano zmiany stężenia progesteronu w kolejnych fazach cyklu estralnego oraz sezonową zmienność stężeń tego hormonu w cyklu estralnym u samic szynszyla małego (Chinchilla laniger Molina, 1782).

Fazę cyklu estralnego określano na podstawie zmian $\mathbf{w}$ obrazie cytologicznym wymazów pochwowych: ilości zrogowaciałych i jądrzastych komórek nabłonka pochwy oraz ilości leukocytów. Ruję określano na podstawie charakterystycznego obrazu cytologicznego wymazów i zmian w wyglądzie zewnętrznych narządów rodnych.

Badania przeprowadzono $w$ trzech okresach roku: okresie pierwszym trwającym od maja do czerwca, drugim trwającym od lipca do września i trzecim trwającym od października do lutego.

Stężenie progesteronu w osoczu krwi oznaczano radioimmunologicznie. Stwierdzono, że stężenie tego hormonu w czasie cyklu estralnego u samic szynszyla waha 
się od 0,1 do $14,0 \mathrm{ng} / \mathrm{ml}$ osocza osiągając wartości najwyższe w fazie metaestrus $(7,21-9,74 \mathrm{ng} / \mathrm{ml})$ a wartości najniższe $\mathrm{w}$ fazie proestrus $(0,4-0,8 \mathrm{ng} / \mathrm{ml})$ (Ryc. 1).

Taki charakter zmian stężenia progesteronu w cyklu estralnym nie zmienia się sezonowo, zmieniają się natomiast istotnie średnie stężenia progesteronu w cyklu. Wartości najniższe notowano w sezonie letnim (od lipca do września, 4,19+ $+0,83 \mathrm{ng} / \mathrm{ml}$ ), w pozostałych dwóch sezonach średnie stężenia progesteronu w cyklu było istotnie wyższe $(6,04+1,07 \mathrm{ng} / \mathrm{ml} \mathrm{w}$ okresie od maja do czerwca, $5,29+$ $+0,70 \mathrm{ng} / \mathrm{ml}$ w okresie od października do lutego) (Tabela 1, Ryc. 2). 